\title{
Campylobacter hominis sp. nov., from the human gastrointestinal tract
}

\author{
Andrew J. Lawson, ${ }^{1}$ Stephen L. W. On, ${ }^{2}$ Julie M. J. Logan ${ }^{1}$ \\ and John Stanley ${ }^{1}$
}

\footnotetext{
${ }^{1}$ Molecular Biology Unit, Virus Reference Division, Central Public Health Laboratory, 61 Colindale Avenue, London NW9 5HT, UK

2 Danish Veterinary Laboratory, Bülowsvej 27, DK-1790 Copenhagen V, Denmark
}

Author for correspondence: John Stanley. Tel: +44 20 82004400. Fax: +44 2082001569. e-mail: sevenwoods@hotmail.com

\begin{abstract}
Sequences of 165 rDNA of a novel campylobacter from faeces of healthy humans were previously shown to originate from a new taxon, ' Candidatus Campylobacter hominis', which could not be cultured. Since phylogenetic analysis suggested that anaerobic conditions might be required for growth, an isolation strategy was developed employing initial non-selective membrane filtration onto fastidious anaerobe agar. Campylobacters were then isolated from the resulting mixed microbial flora by a dilution strategy and/or by immunomagnetic separation with genus-specific polyclonal antibody. Isolates were identified by a genus and taxon-specific PCR assay, and 16S rDNA nucleotide sequence analysis was carried out. All isolates exhibited the typical Campylobacter characteristics of being non-fermentative, oxidase-positive, catalase-negative and Gram-negative. Unusually, however, they were straight rods lacking flagella. The 165 rDNA nucleotide sequence analysis, DNA and mol \% G+C were consistent with a new Campylobacter species whose nearest phylogenetic neighbours were Campylobacter gracilis and Campylobacter sputorum. The unique species status of the isolates was further confirmed by taxonomic analysis of $\mathbf{4 7}$ phenotypic characteristics. The name Campylobacter hominis sp. nov. is proposed for the new species, the type strain of which is NCTC $13146^{\top}$ ( = LMG $19568^{\mathrm{T}}$ ).
\end{abstract}

Keywords: Campylobacter, phylogenetic study, human enteric isolates

\section{INTRODUCTION}

The taxonomy of the genus Campylobacter has undergone extensive revision and expansion in the last decade. Campylobacter is assigned to rRNA superfamily VI, which consists of the family Campylobacteraceae (containing Campylobacter and Arcobacter), the genera Sulfurospirillum, Helicobacter, Wolinella and Thiovulum, and the generically misnamed Bacteroides ureolyticus (Vandamme et al., 1991, 1995; Vandamme \& Goossens, 1992). Campylobacters can be isolated from a variety of environmental samples, but their normal habitat is considered to be the gastrointestinal tract of birds, animals and man. The pathogenic species are associated with infections of the intestinal and genital tracts and the periodontal crevice. The most noteworthy of these infections is

Abbreviation: IMS, immunomagnetic separation.

The EMBL accession number for the sequence reported in this paper is AJ251584 (NCTC 13146').
Campylobacter enteritis, due to Campylobacter jejuni, the most common cause of bacterial gastroenteritis worldwide (Skirrow, 1994).

We previously described the detection and analysis of partial 16S rDNA sequences, obtained by genusspecific PCR from human faecal material of individuals without clinical illness (Lawson et al., 1998). We identified the source of these amplicons as a new taxon, 'Candidatus Campylobacter hominis'. We were unable to isolate the organism from which the $16 \mathrm{~S}$ rDNA sequences originated.

The present study describes the subsequent isolation and characterization of this bacterium, and its full description as Campylobacter hominis sp. nov.

\section{METHODS}

Reference strains and culture conditions. Reference strains of Campylobacter, Arcobacter, Helicobacter and Escherichia coli used in this study are listed in Table 1. All strains were cultured on $5 \%$ blood agar (BA; Oxoid) at $37^{\circ} \mathrm{C}$. Micro- 
Table 1 Bacterial strains and/or 16S rRNA sequences

\begin{tabular}{|c|c|c|c|c|}
\hline Bacteria & Source & Location & Strain designation* & $\begin{array}{c}\text { Sequence } \\
\text { accession no. } \dagger\end{array}$ \\
\hline C. hominis sp. nov & $\begin{array}{l}\text { Human, faeces } \\
\text { Human, faeces } \\
\text { Human, faeces } \\
\text { Human, faeces } \\
\text { Human, faeces }\end{array}$ & $\begin{array}{l}\text { London, UK } \\
\text { London, UK } \\
\text { London, UK } \\
\text { London, UK } \\
\text { London, UK }\end{array}$ & $\begin{array}{l}\mathrm{CH} 001 \mathrm{~A}\left(\mathrm{NCTC} 13146^{\mathrm{T}}\right) \\
\mathrm{CH} 001 \mathrm{~B} \\
\mathrm{CH} 001 \mathrm{C} \\
\mathrm{CH} 002 \\
\mathrm{CH} 003\end{array}$ & $\mathrm{AJ} 251584$ \\
\hline 'Candidatus C. hominis' & $\begin{array}{l}\text { Human, faeces } \\
\text { Human, faeces } \\
\text { Human, faeces }\end{array}$ & $\begin{array}{l}\text { London, UK } \\
\text { London, UK } \\
\text { London, UK }\end{array}$ & $\begin{array}{l}\text { HS-A } \\
\text { HS-B } \\
\text { HS-C }\end{array}$ & $\begin{array}{l}\text { AF062490 } \\
\text { AF062491 } \\
\text { AF062492 }\end{array}$ \\
\hline C. coli & $\begin{array}{l}\text { Porcine, faeces } \\
\text { Porcine, intestine }\end{array}$ & $\begin{array}{l}\text { Brussels, Belgium } \\
\text { Melbourne, Australia }\end{array}$ & $\begin{array}{l}\text { NCTC } 11366^{\mathrm{T}} \\
\text { CCUG } 33450\end{array}$ & L04312 \\
\hline C. concisus & $\begin{array}{l}\text { Human, gingival sulcus } \\
\text { Human, gingival pocket } \\
\text { Human, gingival sulcus } \\
\text { Human, blood } \\
\text { Human, antral biopsy } \\
\text { Human, infant diarrhoea } \\
\text { Human, diarrhoea } \\
\text { Human, oesophageal biopsy } \\
\text { Human, diarrhoea } \\
\text { Human, duodenal aspirate } \\
\text { Human, faeces } \\
\text { Human, diarrhoea } \\
\text { Human, faeces } \\
\text { Human, faeces } \\
\text { Human, diarrhoea }\end{array}$ & $\begin{array}{l}\text { Boston, USA } \\
\text { Boston, USA } \\
\text { Boston, USA } \\
\text { UK } \\
\text { Göteborg, Sweden } \\
\text { Oroboro, Sweden } \\
\text { Oroboro, Sweden } \\
\text { Perth, Australia } \\
\text { Oroboro, Sweden } \\
\text { Ottawa, Canada } \\
\text { Oroboro, Sweden } \\
\text { Oroboro, Sweden } \\
\text { Oroboro, Sweden } \\
\text { Preston, UK } \\
\text { Preston, UK }\end{array}$ & $\begin{array}{l}\text { NCTC } 11485^{\mathrm{T}} \\
\text { NCTC } 11486 \\
\text { NCTC } 11487 \\
\text { CCUG } 10376 \\
\text { CCUG } 14496 \\
\text { CCUG } 17580 \\
\text { CCUG } 18688 \\
\text { CCUG } 19219 \\
\text { CCUG } 19393 \\
\text { CCUG } 19505 \\
\text { CCUG } 19995 \\
\text { CCUG } 19996 \\
\text { CCUG } 20034 \\
\text { CCUG } 20699 \\
\text { CCUG } 20700\end{array}$ & L04322 \\
\hline C. curvus & $\begin{array}{l}\text { Human, alveolar abscess } \\
\text { Human, apical periodontitis } \\
\text { Human, periodontitis } \\
\text { Human, septicaemia } \\
\text { Human }\end{array}$ & $\begin{array}{l}\text { Virginia, USA } \\
\text { Umeå, Sweden } \\
\text { Boston, USA } \\
\text { Wisconsin, USA } \\
\text { USA }\end{array}$ & $\begin{array}{l}\text { NCTC } 11649^{\mathrm{T}} \\
\text { CCUG } 11644 \\
\text { FDC } 521 \\
\text { FDC } 640 \\
\text { ATCC } 29543\end{array}$ & L04313 \\
\hline $\begin{array}{l}\text { Campylobacter fetus subsp. } \\
\text { fetus }\end{array}$ & Ovine, fetus brain & Paris, France & NCTC $10842^{\mathrm{T}}$ & M65012 \\
\hline C. fetus subsp. venerealis & Bovine, vaginal mucus & Reading, UK & NCTC $10354^{\mathrm{T}}$ & \\
\hline C. gracilis & $\begin{array}{l}\text { Human, periodontitis } \\
\text { Human, periodontitis } \\
\text { Human, periodontitis } \\
\text { Human, gingivitis } \\
\text { Human, gingivitis } \\
\text { Human, periodontitis } \\
\text { Human, periodontitis }\end{array}$ & $\begin{array}{l}\text { Boston, USA } \\
\text { Boston, USA } \\
\text { Boston, USA } \\
\text { Boston, USA } \\
\text { Boston, USA } \\
\text { Boston, USA } \\
\text { Boston, USA }\end{array}$ & $\begin{array}{l}\text { NCTC } 12738^{\mathrm{T}} \\
\text { CCUG } 13143 \\
\text { CCUG } 22762 \\
\text { FDC EM } 38 \\
\text { FDC EF19 } \\
\text { FDC } 406 \\
\text { FDC } 1084\end{array}$ & L04320 \\
\hline Campylobacter helveticus & Feline, faeces & Berne, Switzerland & NCTC $12470^{\mathrm{T}}$ & U03022 \\
\hline $\begin{array}{l}\text { Campylobacter hyointestinalis } \\
\text { subsp. hyointestinalis }\end{array}$ & Porcine, intestine & Minnesota, USA & NCTC $11608^{\mathrm{T}}$ & M65010 \\
\hline $\begin{array}{l}\text { C. hyointestinalis subsp. } \\
\text { lawsonii }\end{array}$ & Porcine, stomach & UK & NCTC $12901^{\mathrm{T}}$ & \\
\hline C. jejuni subsp. jejuni & Bovine, faeces & Brussels, Belgium & NCTC $11351^{\mathrm{T}}$ & L04315 \\
\hline C. jejuni subsp. doylei & Human, infantile diarrhoea & Adelaide, Australia & NCTC $11951^{\mathrm{T}}$ & \\
\hline Campylobacter lari & $\begin{array}{l}\text { Herring gull, cloacal swab } \\
\text { River water }\end{array}$ & $\begin{array}{l}\text { UK } \\
\text { UK }\end{array}$ & $\begin{array}{l}\text { NCTC } 11352^{\mathrm{T}} \\
\text { NCTC } 11845\end{array}$ & L04316 \\
\hline Campylobacter mucosalis & $\begin{array}{l}\text { Porcine, intestine } \\
\text { Porcine, intestine } \\
\text { Porcine, necrotic colitis }\end{array}$ & $\begin{array}{l}\text { Edinburgh, UK } \\
\text { Edinburgh, UK } \\
\text { Lothian, UK }\end{array}$ & $\begin{array}{l}\text { NCTC } 11000^{\mathrm{T}} \\
\text { NCTC } 11001 \\
\text { NCTC } 11418\end{array}$ & L06978 \\
\hline
\end{tabular}


Table 1 (cont.)

\begin{tabular}{|c|c|c|c|c|}
\hline Bacteria & Source & Location & Strain designation* & $\begin{array}{c}\text { Sequence } \\
\text { accession no. } \dagger\end{array}$ \\
\hline \multirow{12}{*}{ C. rectus } & $\begin{array}{l}\text { Porcine, adenomatous } \\
\text { colon }\end{array}$ & Lothian, UK & NCTC 11419 & \\
\hline & $\begin{array}{l}\text { Porcine, haemorrrhagic } \\
\text { enterititis }\end{array}$ & Lothian, UK & NCTC 11420 & \\
\hline & Porcine, intestine & UK & CCUG 23201 & \\
\hline & Porcine, intestine & UK & CCUG 23202 & \\
\hline & Porcine, intestine & UK & CCUG 23203 & \\
\hline & Unknown & Brussels, Belgium & CCUG 23204 & \\
\hline & Porcine & Denmark & CCUG 24188 & \\
\hline & Human, periodontal pocket & Boston, USA & NCTC $11489^{\mathrm{T}}$ & L04317 \\
\hline & $\begin{array}{l}\text { Human, apical } \\
\text { periodontitis }\end{array}$ & Umeå, Sweden & CCUG 11640 & \\
\hline & $\begin{array}{l}\text { Human, apical } \\
\text { periodontitis }\end{array}$ & Umeå, Sweden & CCUG 11642 & \\
\hline & $\begin{array}{l}\text { Human, apical } \\
\text { periodontitis }\end{array}$ & Umeå, Sweden & CCUG 11643 & \\
\hline & $\begin{array}{l}\text { Human, apical } \\
\text { periodontitis }\end{array}$ & Umeå, Sweden & CCUG 11645 & \\
\hline \multirow[t]{2}{*}{ C. showae } & Human, gingival crevice & Showa, Japan & NCTC $12843^{\mathrm{T}}$ & L06974 \\
\hline & $\begin{array}{l}\text { Human, apical } \\
\text { periodontitis }\end{array}$ & Umeå, Sweden & NCTC 12843 & \\
\hline \multirow[t]{2}{*}{ C. sputorum bv. faecalis } & Ovine, faeces & Los Angeles, USA & NCTC $11415^{\mathrm{T}}$ & \\
\hline & Ovine, faeces & Canada & CCUG 12015 & \\
\hline $\begin{array}{l}\text { C. sputorum bv. } \\
\text { paraureolyticus }\end{array}$ & Bovine, faeces & $\mathrm{UK}$ & BU 86C & \\
\hline \multirow[t]{2}{*}{ C. sputorum bv. sputorum } & Human, oral cavity & USA & NCTC $11528^{\mathrm{T}}$ & X67775 \\
\hline & Human, pus & Belgium & LMG 14261 & \\
\hline Campylobacter upsaliensis & Canine, faeces & Malmo, Sweden & NCTC $11541^{\mathrm{T}}$ & L14628 \\
\hline \multirow[t]{10}{*}{ [Bacteroides] ureolyticus§ } & Human, amniotic fluid & Edmonton, Canada & NCTC $10941^{\mathrm{T}}$ & L04321 \\
\hline & Human, vagina & Newcastle, UK & NCTC 10948 & \\
\hline & Human, vagina & Newcastle, UK & NCTC 10949 & \\
\hline & Human, urethra & Harrow, UK & NCTC 12014 & \\
\hline & Human, urethra & Harrow, UK & NCTC 12015 & \\
\hline & Human, perianal lesion & Sheffield, UK & NCTC 12016 & \\
\hline & Human, penile wound & Göteborg, Sweden & CCUG 9510D & \\
\hline & Human, penile wound & Göteborg, Sweden & CCUG 9596 & \\
\hline & Human, urine & Göteborg, Sweden & CCUG 18470 & \\
\hline & Human & Göteborg, Sweden & CCUG EF-11762 & \\
\hline Arcobacter skirrowii & Ovine & Göteborg, Sweden & NCTC $12713^{\mathrm{T}}$ & L16625 \\
\hline Helicobacter pylori & Human & Australia & NCTC $11637^{\mathrm{T}}$ & M88157 \\
\hline Escherichia coli & Human & Denmark & NCTC $9001^{\mathrm{T}}$ & J01695 \\
\hline
\end{tabular}

* NCTC, National Collection of Type Cultures; CCUG, Culture Collection of the University of Göteborg; FDC, Forsyth Dental Centre; ATCC, American Type Culture Collection; BU, University of Berne; LMG, Laboratorium voor Microbiology en Microbielle Genetica. ${ }^{\mathrm{T}}$, Type strain.

$\uparrow 16 \mathrm{~S}$ rRNA sequences for these strains are available for electronic retrieval from EMBL under the indicated accession numbers. Through cross-distribution of databases, these sequences should also be available from the GenBank and DDBJ databases.

$\$$ 16S rDNA sequence only (Lawson et al., 1998).

$\S$ Species incertae sedis which is genotypically Campylobacter (Vandamme et al., 1995).

aerophilic species were incubated in an atmosphere of $5 \%$ $\mathrm{O}_{2}, 5 \% \mathrm{CO}_{2}, 2 \% \mathrm{H}_{2}$ and $88 \% \mathrm{~N}_{2}$ (by volume). Anaerobic species were incubated in an atmosphere of $5 \% \mathrm{CO}_{2}, 5 \% \mathrm{H}_{2}$ and $90 \% \mathrm{~N}_{2}$.
Faecal samples. Fresh faecal samples were collected from 18 human subjects with no current or recent gastrointestinal symptoms. They were diluted 1:10 in brucella broth (BB; Life Technologies) and vortexed briefly to produce a 


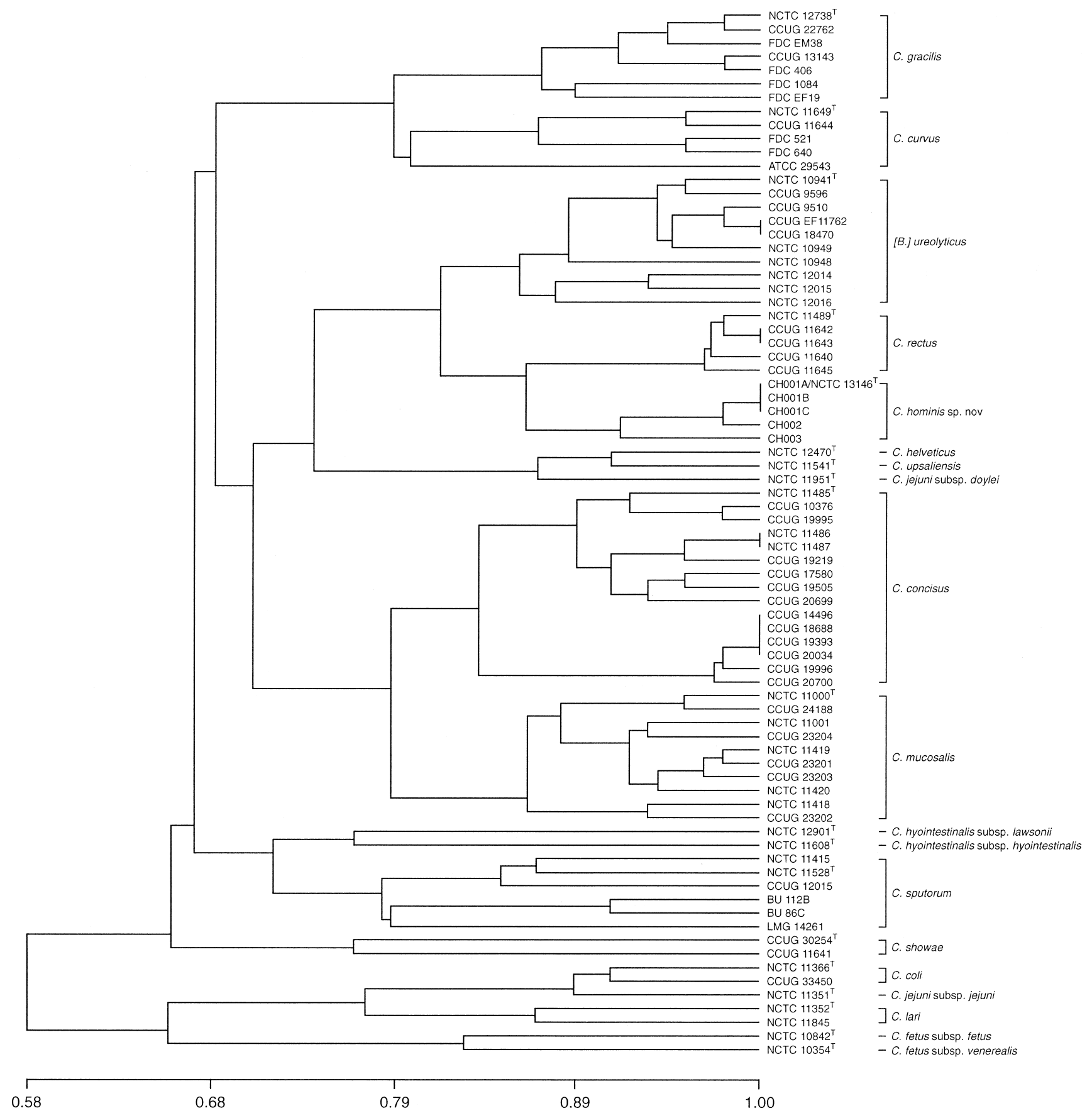

Fig. 1. Dendrogram of cluster analysis based on 47 phenotypic characteristics of Campylobacter strains. Strain numbers on the vertical axis correspond with those in Table 1. The numbers on the horizontal axis indicate the percentage similarities as determined by the simple matching coefficient and unweighted pair group average linkage clustering.

homogeneous suspension. Large particulate matter was allowed to settle out (10 $\mathrm{min})$ and the supernatant was used for culture and PCR (see below).

PCR assay. The faecal supernatants were examined by a PCR assay specific for 'Candidatus C. hominis' (Lawson et al., 1998) and a Campylobacter genus-specific assay (Linton et al., 1996). A subset of DNA samples extracted from diarrhoeic faecal samples in a previous study (Lawson et al., 1999) were also examined. Among these samples, 114 were positive for $C$. jejuni by culture and $C$. jejuni-specific PCRs (Linton et al., 1997; Metherell et al., 1999), while 95 contained no enteropathogenic Campylobacter species by either culture or PCR.

Isolation procedures. Faecal samples were examined for Campylobacter species by culture on modified charcoal cefoperazone deoxycholate agar (CCDA; Oxoid) and by the membrane filter method (Bolton et al., 1988; Steele \& McDermott, 1984). Cellulose acetate membrane filters of 
$0.65 \mu \mathrm{m}$ pore size (Sartorius) were applied to BA or fastidious anaerobe agar (FAA; Lab M). Plates were incubated for up to $21 \mathrm{~d}$ at $37^{\circ} \mathrm{C}$ under either microaerobic or anaerobic conditions (as above) and examined at regular intervals. Mixtures of bacterial growth or campylobacterlike colonies were screened by PCR assays for the genus Campylobacter and the Candidatus status taxon.

Where a mixed growth was 'Candidatus C. hominis' PCRpositive, a pure culture of campylobacter-like colonies was obtained by either dilution or immunomagnetic separation (IMS) (see below). In the former case, a colony sweep using a $10 \mu$ loop was resuspended in $1 \mathrm{ml} \mathrm{BB}$ and diluted $10^{-1}$, $10^{-2}, 10^{-3}, 10^{-4}$ in this medium. The $10^{-3}$ and $10^{-4}$ dilutions were inoculated on FAA and incubated anaerobically for $10-20 \mathrm{~d}$

Immunomagnetic separation (IMS). Two commercially prepared antibodies specific for the genus Campylobacter were employed. These were an anti-flagella mouse monoclonal (Chemicon International) and a goat polyclonal antibody specific for cell wall components (Kirkegard and Perry Labs). For IMS of 'Candidatus C. hominis', a bacterial suspension was made in $50 \mu \mathrm{l} \mathrm{BB}$ and mixed with $100 \mu \mathrm{l}$ of an antibody preparation pre-diluted to a working concentration of $20 \mu \mathrm{g} \mathrm{ml}^{-1}$. This was incubated at $40{ }^{\circ} \mathrm{C}$ with occasional mixing for $30 \mathrm{~min}$. Cells were pelleted by centrifugation (13000 $\boldsymbol{g}$ for $1 \mathrm{~min}$ ). The supernatant was discarded and the pellet washed three times with $1 \mathrm{ml} \mathrm{BB}$. The pellet was resuspended in $900 \mu \mathrm{l} \mathrm{BB}$ and mixed with $100 \mu \mathrm{l}$ of a $5 \mathrm{mg} \mathrm{ml}^{-1}$ suspension of BioMag, protein-G-coated, magnetic beads (PerSeptive Diagnostics). This was incubated at room temperature for $15 \mathrm{~min}$ with gentle mixing. Beads were recovered with a magnetic particle concentrator, and washed three times in BB. The bound bacterial cells were then plated out and incubated anaerobically (see Results). The positive and negative controls were $C$. jejuni NCTC $11351^{\mathrm{T}}$ and $E$. coli NCTC $9001^{\mathrm{T}}$.

Phenotypic characterization and numerical analysis. Isolates were initially characterized by oxidase, catalase, Gram stain and hanging drop motility as previously described (Barrow \& Feltham, 1993). A more extensive analysis of the phenotypic characteristics of the isolates and control strains was undertaken using 47 phenotypic tests with media and methodologies as recommended previously (On \& Holmes, 1991a, b, 1992). All tests were performed on two separate occasions using freshly prepared media whose quality was assured by appropriate control strains. Numerical analysis of the phenotypic data was performed as previously described (On \& Holmes, 1995). Briefly, the simple matching coefficient was used to calculate the similarity between strains and a dendrogram which reflected these levels of similarity was constructed. Strains were clustered by the unweighted pair group with the mathematical average (UPGMA) method.

Electron microscopy. Cells were resuspended in $1 \%(\mathrm{v} / \mathrm{v})$ formalin solution. A Formvar-coated grid was placed on a drop of the bacterial suspension for $2 \mathrm{~min}$, and transferred to a drop of $2 \%(\mathrm{w} / \mathrm{v})$ ammonium molybdate solution for a further $2 \mathrm{~min}$. Grids were dried at the end of each step by touching their edge to filter paper. Grids were examined at $\times 13500$ magnification in a Phillips EM420 electron microscope at $80 \mathrm{kV}$.

Sequencing of $16 \mathrm{~S}$ rDNA and phylogenetic analysis. Campylobacter genus-specific 16S rDNA amplified from DNA extracted from one of the putative $C$. hominis isolates (strain CH001A) was sequenced as previously described

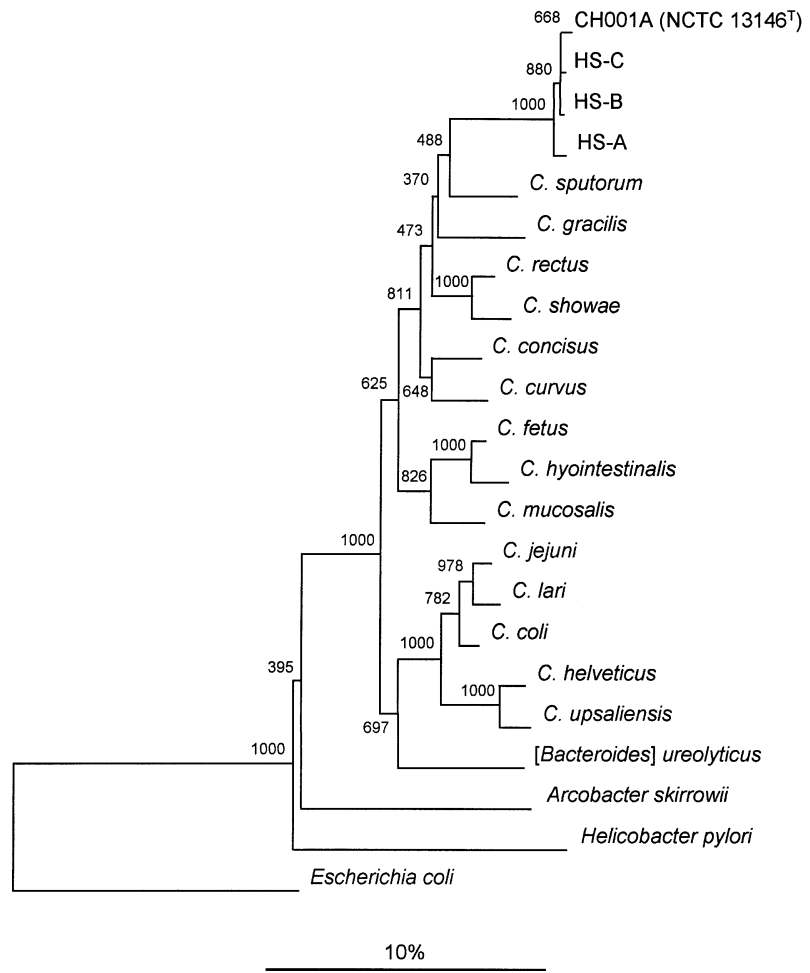

Fig. 2. Phylogenetic tree of the $16 \mathrm{~S}$ rDNA sequences of Campylobacter species determined by neighbour-joining analysis. The sequence of $E$. coli was used as the outgroup. The strain numbers and sequence accession numbers are given in Table 1.

(Stanley et al., 1993) using an ABI PRISM dye terminator cycle sequencing kit (Perkin Elmer). Sequences were aligned by the CLUSTAL method with the three 16S rDNA sequences of 'Candidatus C. hominis' (Lawson et al., 1998) and species type strain reference sequences obtained from the EMBL database (Table 1), using Megalign from the Lasergene suite of programs (DNAstar). The data were used to create a phylogenetic tree (Fig. 2) using the neighbour-joining method (Saitou \& Nei, 1987) as implemented in the TREECON package (van de Peer \& de Wachter, 1993). Ambiguous bases were removed and the remaining 1375 bases were analysed using the method of Jukes \& Cantor (1969). Bootstrap analysis was performed with 1000 resampled data sets.

Nucleic acid techniques. Genomic DNA was prepared from representative species as previously described (Stanley et al., 1992). DNA base composition ( $\mathrm{mol} \% \mathrm{G}+\mathrm{C}$ content) was estimated from the thermal denaturation temperature (Owen \& Pitcher, 1985). DNA-DNA slot-blot hybridization was performed on genomic DNA isolated from the species type strains listed in Table 1, using DNA of CH001A (see below) as the probe. The method was as previously described (Stanley et al., 1992), except that a Digoxigenin (DIG) High Prime labelling and detection kit was used (Roche) and hybridization was performed under optimal renaturation conditions: $2 \times \operatorname{SSC}(0.3 \mathrm{M} \mathrm{NaCl}, 0.3 \mathrm{M}$ sodium citrate $)$ at $62{ }^{\circ} \mathrm{C}$. Density analysis was performed using an Agfa scanner and Scan Analysis software (ver. 2.21; Biosoft) to determine homology values relative to self-hybridization of the probe with target DNA of $\mathrm{CH} 001 \mathrm{~A}$. 


\section{RESULTS}

\section{Detection and isolation of the bacterium}

Amplicons specific for 'Candidatus C. hominis' were found in five out of $18(26.8 \%)$ healthy faecal samples examined directly by DNA extraction and specific PCR assay. Fresh faecal samples were obtained from these five individuals for culture examination (see Methods). After $21 \mathrm{~d}$ microaerobic incubation, plates showed little or no growth and all such growth was negative by Campylobacter genus-specific and by 'Candidatus C. hominis'-specific PCR assays. CCDA incubated anaerobically was similarly negative. Plates inoculated using the membrane filter method produced confluent mixed bacterial growth, when incubated anaerobically. Four out of five samples from anaerobic FAA colony sweeps were positive by both Campylobacter genus-specific PCR and 'Candidatus C. hominis'-specific PCR. They were further examined by the dilution and IMS methods described above. All anaerobic BA plates were PCR-negative by both assays.

The dilution approach was successful in one of the five samples. In this case, three distinct colony types were detected from a single faecal sample, all ' Candidatus $\mathrm{C}$. hominis'-specific PCR-positive. These were termed CH001A (1.0 mm diameter, grey, flat, spreading),
CH001B ( $0.5 \mathrm{~mm}$ diameter, grey, convex, entire) and CH001C (1.0 mm diameter, grey, convex, entire).

'Candidatus C. hominis'-specific PCR-positive material was also investigated by IMS. One millilitre of bacterial suspension was mixed with biomagnetic beads coated with either flagella-specific or cell-wallspecific antibody. Using this approach, the cell-wallspecific IMS yielded 'Candidatus $\mathrm{C}$. hominis' PCRpositive colonies, $\mathrm{CH} 002$ and $\mathrm{CH} 003$, each from two further individual samples. These isolates were both similar in appearance to colony type A of $\mathrm{CH} 001$. IMS with flagellin-specific antibody was unsuccessful.

The above combination of strategies yielded 'Candidatus C. hominis' PCR-positive colonies from three of the five individuals whose faecal samples were positive by the same assay performed directly on DNA extracted from the faeces.

\section{Phenotypic characterization and numerical analysis}

We observed that strains could be successfully grown on ordinary $5 \%$ BA media after a few subcultures on FAA, although anaerobic conditions were essential. Growth was either not obtained, or was of a notably poor quality, under microaerobic conditions.

Isolates of $C$. hominis were phenotypically homogeneous, with infraspecific variance detected in only

Table 2 Characteristics differentiating C. hominis sp. nov. from other Campylobacter species

Phenotypic data on $C$. hominis were as described in this study. The characteristics of the other taxa were from previous studies and were determined by the same methods (On et al., 1996, 1998). +, All strains positive; - , all strains negative; (+), 70-97\% strains positive; (-), 5-30\% strains positive; v, 38-66\% strains positive.

\begin{tabular}{|c|c|c|c|c|c|c|c|c|c|c|c|c|c|}
\hline & \multicolumn{5}{|c|}{ Production of: } & \multicolumn{2}{|c|}{ Hydrolysis of: } & \multicolumn{5}{|c|}{ Tolerance to: } & \multirow{2}{*}{$\begin{array}{c}\text { Presence o } \\
\text { flagella }\end{array}$} \\
\hline & Oxidase & Catalase & Urease & $\begin{array}{c}\text { Alkaline } \\
\text { phosphatase }\end{array}$ & $\begin{array}{l}\mathrm{H}_{2} \mathrm{~S} \\
\text { (TSI) }\end{array}$ & Hippurate & $\begin{array}{l}\text { Indoxyl } \\
\text { acetate }\end{array}$ & $\begin{array}{c}\text { TTC } \\
(0.04 \%)\end{array}$ & $\begin{array}{l}\text { Metronidazole } \\
\quad\left(4 \mathrm{mg}^{-1}\right)\end{array}$ & $\begin{array}{l}\text { 5-Fluorouracil } \\
\left(100 \mathrm{U} \mathrm{I}^{-1}\right)\end{array}$ & $\begin{array}{c}\text { Crystal } \\
\text { violet }\end{array}$ & $\begin{array}{l}\text { Sodium } \\
\text { fluoride }\end{array}$ & \\
\hline $\begin{array}{l}\text { Campylobacter } \\
\text { hominis sp. nov }\end{array}$ & + & - & - & - & - & - & - & - & - & + & - & + & - \\
\hline C. coli & + & + & - & - & $\mathrm{v}$ & - & + & + & $(+)$ & + & $\mathrm{v}$ & + & + \\
\hline C. concisus & $\mathrm{v}$ & - & - & $(+)$ & $(-)$ & - & - & - & $(-)$ & $(-)$ & $\mathrm{v}$ & $(+)$ & + \\
\hline C. curvus & + & - & - & $\mathrm{v}$ & $(-)$ & $(-)$ & $\mathrm{v}$ & + & - & $(-)$ & + & - & + \\
\hline C. fetus subsp. fetus & + & + & - & - & - & - & - & - & $(+)$ & + & + & $(+)$ & + \\
\hline $\begin{array}{l}\text { C. fetus subsp. } \\
\text { venerealis }\end{array}$ & + & $(+)$ & - & - & - & - & - & - & $\mathrm{v}$ & $(+)$ & $(+)$ & $(+)$ & + \\
\hline C. gracilis & - & $(-)$ & - & - & - & - & $(+)$ & - & - & $(-)$ & + & $(+)$ & - \\
\hline C. helveticus & + & - & - & - & - & - & + & - & $\mathrm{v}$ & + & - & - & + \\
\hline $\begin{array}{l}\text { C. hyointestinalis subsp. } \\
\text { hyointestinalis }\end{array}$ & + & + & - & - & $(+)$ & - & - & $(-)$ & $(-)$ & $(-)$ & $(+)$ & $\mathrm{v}$ & + \\
\hline $\begin{array}{l}\text { C. hyointestinalis subsp. } \\
\text { lawsonii }\end{array}$ & + & + & - & $(-)$ & $(+)^{*}$ & - & - & - & $\mathrm{v}$ & $\mathrm{v}$ & $\mathrm{v}$ & - & + \\
\hline C. jejuni subsp. doylei & + & $(+)$ & - & - & - & + & + & $\mathrm{v}$ & $(-)$ & + & - & $(-)$ & + \\
\hline C. jejuni subsp. jejuni & + & + & - & - & - & + & + & $(+)$ & $(+)$ & $(+)$ & $\mathrm{v}$ & + & + \\
\hline C. lari & + & + & $\mathrm{v}^{\dagger}$ & $(-)$ & - & - & $(-)$ & $(+)$ & + & + & $\mathrm{v}$ & + & + \\
\hline C. mucosalis & + & - & - & $(+)$ & + & - & - & - & $(+)$ & - & $(+)$ & - & + \\
\hline C. rectus & + & $(-)$ & - & - & - & - & + & - & - & - & - & - & + \\
\hline C. showae & $\mathrm{v}$ & + & - & - & $\mathrm{v}$ & - & $\mathrm{v}$ & - & + & - & + & + & + \\
\hline C. sputorum & + & $\mathrm{v} \dagger$ & $\mathrm{v} \dagger$ & - & $(+)^{*}$ & - & - & - & $(-)$ & - & v & $(+)$ & + \\
\hline C. upsaliensis & + & - & - & - & - & - & + & - & $(+)$ & + & - & - & + \\
\hline [B.] ureolyticus & + & $(-)$ & + & - & - & - & $(-)$ & - & - & - & $(-)$ & + & + \\
\hline
\end{tabular}

* Strains of C. sputorum and C. hyointestinalis subsp. lawsonii normally produce copious amounts of $\mathrm{H}_{2} \mathrm{~S}$ in TSI agar slopes.

$\dagger$ Results for strains in these tests are biovar-dependent (On et al., 1996, 1998).

$\downarrow$ Phylogenetically closely related to Campylobacter and generically misnamed, but considered a species incertae sedis (Vandamme et al., 1995). 
$4 / 47$ test results. These were nitrate reduction $(\mathrm{CH} 004$ and $\mathrm{CH} 005$ positive), tolerance to 1.0 and $2.0 \%$ bile (CH004 positive), and resistance to nalidixic acid (CH004 sensitive). The phenotypic characteristics of C. hominis are listed in the formal description.

Table 2 lists the most useful characteristics differentiating $C$. hominis from other Campylobacter species. Biochemically, $C$. hominis is most similar to the principally anaerobic hydrogen-requiring species Campylobacter concisus, Campylobacter curvus, Campylobacter gracilis, Campylobacter rectus, Campylobacter showae and Campylobacter sputorum, to which a close phylogenetic relationship is evident (Fig. 1). Nonetheless, the dendrogram derived from a numerical analysis of the 47 phenotypic tests used shows that the $C$. hominis strains form a distinct cluster at the $92.0 \%$ similarity level and are readily distinguished from all other Campylobacter species (Fig. 2).

\section{S rRNA gene sequence}

The 16S rRNA gene sequence (1414 nucleotides) was obtained from genomic DNA extracted from CH001A. Phylogenetic analysis showed that this sequence clustered among the sequences of 'Candidatus C. hominis' previously determined directly from faecal material (Fig. 2). It was $0.7 \%$ divergent from HS-A, and $0 \cdot 1 \%$ from HS-B and HS-C. The overall phylogenetic position for $\mathrm{CH} 001 \mathrm{~A}$ was the same as that for 'Candidatus C. hominis' (Lawson et al., 1998). Dissimilarities between $\mathrm{CH} 001 \mathrm{~A}$ and the most closely related species were as follows: C. sputorum, $6.2 \%$; C. gracilis, $6.7 \%$; C. rectus, $7.0 \%$; C. concisus, $7.4 \%$; C. showae, $7 \cdot 4 \%$; and C. curvus, $8.3 \%$. Other dissimilarities included: C. jejuni, 10.5\%; Arcobacter skirrowii, $15 \cdot 7 \%$; Helicobacter pylori, $18 \cdot 1 \%$; and $E$. coli, $28 \cdot 7 \%$.

\section{DNA base composition and DNA-DNA hybridization}

DNAs of strains $\mathrm{CH} 001 \mathrm{~A}, \mathrm{CH} 002$ and $\mathrm{CH} 003$ were subjected to further analysis. The DNA base composition of these strains was determined as 32$33 \mathrm{~mol} \% \mathrm{G}+\mathrm{C}$.

The relative homology values obtained by DNA-DNA hybridization at $62^{\circ} \mathrm{C}$ using $\mathrm{CH} 001 \mathrm{~A}$ DNA as probe were as follows: $\mathrm{CH} 001 \mathrm{~A}, 100 \%$; $\mathrm{CH} 002,91.4 \%$; and $\mathrm{CH} 003,98.7 \%$. All other Campylobacter type species, H. pylori, A. skirrowii and E. coli showed no detectable homology.

\section{Electron microscopy}

Examples of electron micrographs are presented in Fig. 3(a, b). Cells were typically blunt-ended bacilli or coccobacilli, $0.25-0.5 \mu \mathrm{m}$ wide and $0.5-1.8 \mu \mathrm{m}$ long. There was no evidence of spiral morphology or flagella. Cells of colony types that exhibited a spreading morphology (CH001A, $\mathrm{CH} 002$ and $\mathrm{CH} 003$ ) were found to possess numerous irregular fimbriae-like

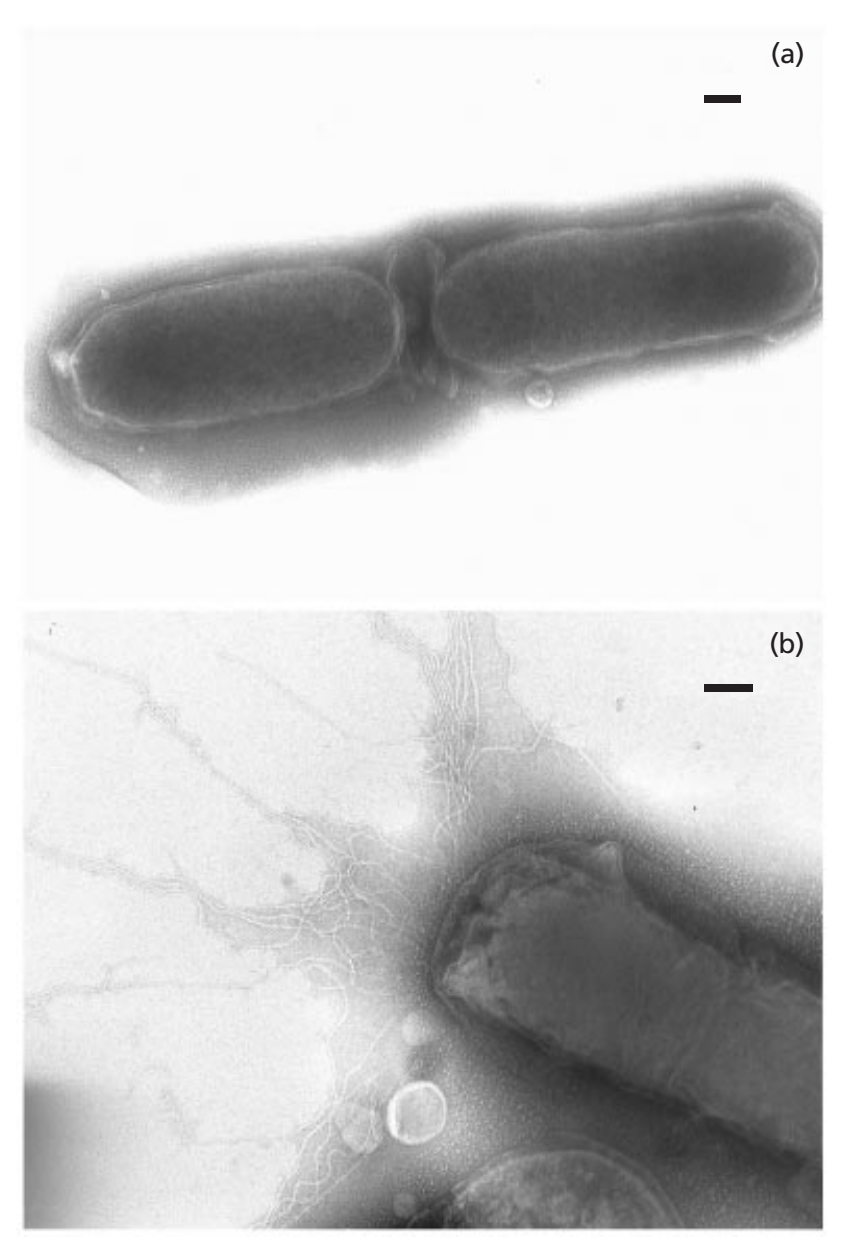

Fig. 3. Electron micrograph of $C$. hominis sp. nov. Bar, $0 \cdot 1 \mu \mathrm{m}$. (a) $\mathrm{CHOO1}$ (colony type B); (b) $\mathrm{CHOO1}$ (colony type A) showing fimbriae-like structures.

structures $4-8 \mathrm{~nm}$ wide and $>1 \cdot 0 \mu \mathrm{m}$ long (Fig. $3 \mathrm{~b}$ ). Fimbriae-like structures were not found in the nonspreading colony types ( $\mathrm{CH} 001 \mathrm{~B}$ and $\mathrm{CH} 001 \mathrm{C})$ of the first strain.

\section{Taxonomic status of $C$. hominis sp. nov.}

The results described provide evidence that the strains isolated and examined in this study (CH001, $\mathrm{CH} 002$ and $\mathrm{CH} 003$ ) constitute a distinct species within the genus Campylobacter, for which we propose the name C. hominis sp. nov. The type strain is $\mathrm{CH}_{001 \mathrm{~A}^{\mathrm{T}}}$ and has been deposited in the National Collection of Type Cultures and designated NCTC $13146^{\mathrm{T}}$.

\section{Prevalence of C. hominis sp. nov. in diarrhoeic faeces}

The species-specific PCR was positive in 10 of 114 $(8 \cdot 8 \%)$ diarrhoeic faecal samples positive for $C$. jejuni. It was also positive in eight of $95(8.4 \%)$ diarrhoeic faecal samples which contained no enteropathogenic Campylobacter species (see Methods). Thus there was no statistical difference in the detection rate for $C$. 
hominis sp. nov. in these two groups (McNemars test, $P>0 \cdot 5$; Swinscow, 1996).

\section{DISCUSSION}

We previously described the presence in faecal samples from healthy humans of novel $16 \mathrm{~S}$ rDNA sequences of Campylobacter origin. These were non-chimeric, folded to a rRNA secondary structure typical of the genus, and corresponded to a novel, uncultured taxon of Campylobacter. In accordance with recommendations for the description of incompletely described prokaryotes (Murray \& Schleifer, 1994; Murray \& Stackebrandt, 1995), the provisional taxon was named 'Candidatus C. hominis' (Lawson et al., 1998).

We were unable to isolate $C$. hominis sp. nov. by conventional Campylobacter isolation methods; this was most likely related to the fastidious growth requirements of the organism, as reported herein. Culture from PCR-positive faecal samples was achieved only after incubation under anaerobic conditions on FAA (a rich medium which contains vitamin $\mathrm{K}$, haemin, cysteine hydrochloride and L-arginine) in combination with dilution or IMS to isolate bacteria from a mixed culture. It is noteworthy that $16 \mathrm{~S}$ rDNA sequence analysis of $C$. hominis identified its closest phylogenetic relatives as $C$. gracilis, $C$. rectus, $C$. curvus, C. showae, C. concisus and C. sputorum. These species form a distinctive clade, including $C$. hominis, within the genus Campylobacter (Fig. 2). They all show a requirement for growth in an anaerobic environment, and/or require $\mathrm{H}_{2}$ for optimum growth (Etoh et al., 1993; Tanner et al., 1981; Vandamme \& Goossens, 1992). Furthermore, most of these species are associated with the periodontal crevice of humans and are rarely associated with gastroenteritis. Several share similar cell morphologies: for example, both $C$. hominis sp. nov. and $C$. gracilis are aflagellate straight rods, whilst $C$. showae and $C$. concisus are flagellate straight rods (Etoh et al., 1993; Tanner et al., 1981). Thus overall phylogenetic, physiological, morphological and ecological properties of these species suggest that they may have a common ancestor within the genus Campylobacter. Furthermore, the relatively deep branching of $C$. hominis sp. nov. and $C$. gracilis observed in the phylogenetic tree, as well as their unusual aflagellate rod-like cell structure, may indicate that these two species represent a distinct lineage within Campylobacter. Other similar such species may await description. However, despite the similarity of C. hominis sp. nov. to C. gracilis, its $\mathrm{mol} \% \mathrm{G}+\mathrm{C}$ value and $16 \mathrm{~S}$ rDNA sequence are closer to that of $C$. sputorum, while the bootstrap value for the branching order to its two nearest neighbours $(C$. sputorum and C. gracilis) by $16 \mathrm{~S}$ rDNA analysis was low (488 and 370, respectively, see Fig. 2). Also DNA-DNA hybridization showed no relative homology with other Campylobacter species. Thus the relative importance of these inferred phylogenetic relationships must remain speculative. The numerous irregular fimbriaelike structures produced by certain colony types of $C$. hominis sp. nov. are also distinct from the few examples of fimbriae reported for Campylobacter species (Dolg et al., 1996).

We previously demonstrated that 'Candidatus C. hominis' $16 \mathrm{~S}$ rDNA sequences were present in $50 \%$ of faecal samples but absent in saliva samples of healthy individuals (Lawson et al., 1998). In the present study, C. hominis-specific PCR was positive in $27.8 \%$ of healthy human faecal samples but only in $8.6 \%$ of diarrhoeic faeces. These findings may be explained if C. hominis sp. nov. is a commensal of the human gastrointestinal tract which is either displaced or drops below the threshold of detection during episodes of acute gastroenteritis. Carriage of a commensal Campylobacter species in the lower gastrointestinal tract might confer protective immunity, or resistance to colonization by pathogenic campylobacters such as $C$. jejuni and Campylobacter coli. However, there was no significant difference between detection rate for $C$. hominis sp. nov. in cases of Campylobacter enteritis or non-Campylobacter enteritis. We note that some isolates of the new species were unable to tolerate $1.0 \%$ bile in laboratory conditions. In contrast, other enteric Campylobacter species, such as C. jejuni, tolerate bile concentrations of between 1.5 and $2.0 \%$ (On et al., 1996). In humans, the initial site of infection of $C$. jejuni is the jejunum and upper ileum (Skirrow, 1994), where bile salt concentrations are high. Bile salts are largely absorbed in the terminal ileum (Percy-Robb \& Collee, 1972), suggesting that the primary niche of $C$. hominis sp. nov. is the large intestine.

\section{Description of Campylobacter hominis sp. nov.}

Campylobacter hominis (hom.in'is. L. gen. n. hominis of man, from which the bacterium was first isolated).

Gram-negative, non-spore-forming rods $0 \cdot 25-0 \cdot 5 \mu \mathrm{m}$ wide and $0.5-1.8 \mu \mathrm{m}$ long after $10 \mathrm{~d}$ incubation (first subculture following initial isolation) on FAA in an anaerobic atmosphere. Colonies pinpoint to $1.0 \mathrm{~mm}$ in diameter, grey, some convex and entire, others flat and spreading. Cells are straight, blunt-ended bacilli or coccobacilli. Non-motile: flagella are not evident but certain isolates produce numerous irregular fimbriaelike structures (4-8 nm wide and $>1.0 \mu \mathrm{m}$ long). Optimal growth achieved on FAA under anaerobic conditions at $37^{\circ} \mathrm{C}$, but strains will grow on standard $5 \%$ blood agar media after adaptation to laboratory conditions. Neither green or blue-green pigmented growth is observed on BA. Pitting of the agar growth medium is absent. Non-haemolytic. No, or extremely poor, growth is attained on either FAA or BA when incubated microaerobically at $37^{\circ} \mathrm{C}$. No growth under aerobic conditions at either 25 or $37^{\circ} \mathrm{C}$. Oxidasepositive. Catalase, hippuricase, urease and alkaline phosphatase are not produced. Hydrogen sulphide is not produced in triple-sugar iron medium. Indoxyl acetate is not hydrolysed. Neither triphenyltetrazolium chloride (TTC) nor selenite is reduced. All strains grow under anaerobic conditions on media 
containing $1.0 \%$ glycine, 5-fluorouracil $\left(100 \mathrm{U}^{-1}\right)$, $0 \cdot 1 \%$ sodium fluoride and $0 \cdot 1 \%$ trimethylamine $\mathrm{M}$ oxide (TMAO). No growth observed under anaerobic conditions at room temperature $\left(18-22{ }^{\circ} \mathrm{C}\right), 25^{\circ} \mathrm{C}$ or $42{ }^{\circ} \mathrm{C}$, or on media containing $4.0 \% \mathrm{NaCl}, 0.04 \%$ TTC, $0.1 \%$ potassium permanganate, $0.001 \%$ sodium arsenite, $32 \mathrm{mg}$ cephalothin $1^{-1}, 4 \mathrm{mg}$ metronidazole $1^{-1}, 32 \mathrm{mg}$ carbenicillin $1^{-1}$ (nutrient and blood agar bases), $0.005 \%$ basic fuchsin, $0.0005 \%$ crystal violet, $0.1 \%$ janus green, $0.1 \%$ sodium deoxycholate or $0.02 \%$ pyronin. No growth similarly observed on a minimal medium, or MacConkey, casein or tyrosine media. Strains may differ in their ability to reduce nitrate, and grow on media containing $1.0 \%$ and $2.0 \%$ bile, and nalidixic acid $\left(32 \mathrm{mg} \mathrm{l}^{-1}\right)$. NCTC $13146^{\mathrm{T}}$ (= LMG $19568^{\mathrm{T}}$ ) is the type strain of $C$. hominis sp. nov. This strain conforms to the species description given above. The $\mathrm{G}+\mathrm{C}$ content of NCTC $13146^{\mathrm{T}} \mathrm{DNA}$ was $32.5 \mathrm{~mol} \%$. The strain was isolated from the faeces of a healthy adult human male (London, UK) in 1998.

\section{ACKNOWLEDGEMENTS}

This work was supported by a grant from the Department of Health, London (DH220B). We thank Dr H. Chart for help with electron microscopy.

\section{REFERENCES}

Barrow, G. I. \& Feltham, R. K. A. (1993). Cowan and Steeles Manual for the Identification of Medical Bacteria. Cambridge: Cambridge University Press.

Bolton, F. J., Hutchinson, D. N. \& Parker, G. (1988). Reassessment of selective agars and filtration techniques for isolation of Campylobacter species from faeces. Eur J Clin Microbiol Infect Dis 7, 155-160.

Dolg, P., Yao, R., Burr, D. H., Guerry, P. \& Trust, T. J. (1996). An environmentally regulated pilus-like appendage involved in Campylobacter pathogenesis. Mol Microbiol 20, 885-894.

Etoh, Y., Dewhirst, F. E., Paster, B. J., Yamamoto, A. \& Goto, N. (1993). Campylobacter showae sp. nov., isolated from the human oral cavity. Int J Syst Bacteriol 43, 631-639.

Jukes, T. H. \& Cantor, C. R. (1969). Evolution of protein molecules. In Mammalian Protein Metabolism, pp. 21-132. Edited by H. N. Munro. New York: Academic Press.

Lawson, A. J., Linton, D. \& Stanley, J. (1998). 16S rRNA gene sequences of 'Candidatus Campylobacter hominis', a novel uncultivated species, are found in the gastrointestinal tract of healthy humans. Microbiology 144, 2063-2071.

Lawson, A. J., Logan, J. M., O’Neill, G. L., Desai, M. \& Stanley, J. (1999). Large-scale survey of Campylobacter species in human gastroenteritis by PCR and PCR-enzyme-linked immunosorbent assay. J Clin Microbiol 37, 3860-3864.

Linton, D., Owen, R. J. \& Stanley, J. (1996). Rapid identification by PCR of the genus Campylobacter and of five Campylobacter species enteropathogenic for man and animals. Res Microbiol 147, 707-718.

Linton, D., Lawson, A. J., Owen, R. J. \& Stanley, J. (1997). PCR detection, identification to species level, and fingerprinting of Campylobacter jejuni and Campylobacter coli direct from diarrheic samples. J Clin Microbiol 35, 2568-2572.

Metherell, L. A., Logan, J. M. \& Stanley, J. (1999). PCR-enzyme- linked immunosorbent assay for detection and identification of Campylobacter species: application to isolates and stool samples. J Clin Microbiol 37, 433-435.

Murray, R. G. E. \& Schleifer, K. H. (1994). Taxonomic notes: a proposal for recording the properties of putative taxa of procaryotes. Int J Syst Bacteriol 44, 174-176.

Murray, R. G. E. \& Stackebrandt, E. (1995). Taxonomic note: implementation of the provisional status Candidatus for incompletely described procaryotes. Int $J$ Syst Bacteriol 45, 186-187.

On, S. L. W. \& Holmes, B. (1991a). Effect of inoculum size on the phenotypic characterization of Campylobacter species. J Clin Microbiol 29, 923-926.

On, S. L. W. \& Holmes, B. (1991b). Reproducibility of tolerance tests that are useful in the identification of campylobacteria. $J$ Clin Microbiol 29, 1785-1788.

On, S. L. W. \& Holmes, B. (1992). Assessment of enzyme detection tests useful in identification of campylobacteria. J Clin Microbiol 30, 746-749.

On, S. L. W. \& Holmes, B. (1995). Classification and identification of campylobacter, helicobacters and allied taxa by numerical analysis of phenotypic characters. Syst Appl Microbiol 18, 374-390.

On, S. L. W., Holmes, B. \& Sackin, M. J. (1996). A probability matrix for the identification of campylobacters, helicobacters and allied taxa. J Appl Bacteriol 81, 425-432.

On, S. L. W., Atabay, H. I., Corry, J. E., Harrington, C. S. \& Vandamme, P. (1998). Emended description of Campylobacter sputorum and revision of its infrasubspecific (biovar) divisions, including $C$. sputorum biovar paraureolyticus, a urease-producing variant from cattle and humans. Int J Syst Bacteriol 48, 195-206.

Owen, R. J. \& Pitcher, D. G. (1985). Chemical methods for estimating DNA base compositions and levels of DNA-DNA hybridization. In Chemical Methods in Bacterial Systematics, pp. 67-93. Edited by M. Goodfellow \& D. E. Minnikin. London: Academic Press.

van de Peer, Y. \& de Wachter, R. (1993). TREECON: a software package for the construction and drawing of evolutionary trees. Comput Appl Biosci 9, 177-182.

Percy-Robb, I. W. \& Collee, J. G. (1972). Bile acids: a pH dependent antibacterial system in the gut? $\mathrm{Br}$ Med J 3, 813-815.

Saitou, N. \& Nei, M. (1987). The neighbor-joining method: a new method for reconstructing phylogenetic trees. Mol Biol Evol 4, 406-425.

Skirrow, M. B. (1994). Diseases due to Campylobacter, Helicobacter and related bacteria. J Comp Pathol 111, 113-149.

Stanley, J., Burnens, A. P., Linton, D., On, S. L., Costas, M. \& Owen, R. J. (1992). Campylobacter helveticus sp. nov., a new thermophilic species from domestic animals: characterization, and cloning of a species-specific DNA probe. J Gen Microbiol 138, 2293-2303.

Stanley, J., Linton, D., Burnens, A. P., Dewhirst, F. E., Owen, R. J., Porter, A., On, S. L. \& Costas, M. (1993). Helicobacter canis sp. nov., a new species from dogs: an integrated study of phenotype and genotype. J Gen Microbiol 139, 2495-2504.

Steele, T. W. \& McDermott, S. N. (1984). The use of membrane filters applied directly to the surface of agar plates for the isolation of Campylobacter jejuni from faeces. Pathology 16, 263-265.

Swinscow, S. D. V. (1996). Statistics at Square One, 9th edn. London: BMJ Publishing Group. 
Tanner, A. C. R., Badger, S., Lai, C. H., Listgarten, M. A., Visconti, R. A. \& Socransky, S. S. (1981). Wolinella gen. nov., Wolinella succinogenes (Vibrio succinogenes Wolin et al.) comb. nov., and description of Bacteroides gracilis sp. nov., Wolinella recta sp. nov., Campylobacter concisus sp. nov., and Eikenella corrodens from humans with periodontal disease. Int J Syst Bacteriol 31, 432-435.

Vandamme, P. \& Goossens, H. (1992). Taxonomy of Campylobacter, Arcobacter, and Helicobacter: a review. Zentbl Bakteriol 276, 447-472.
Vandamme, P., Falsen, E., Rossau, R., Hoste, B., Segers, P., Tytgat, R. \& de Ley, J. (1991). Revision of Campylobacter, Helicobacter, and Wolinella taxonomy: emendation of generic descriptions and proposal of Arcobacter gen. nov. Int J Syst Bacteriol 41, 88-103.

Vandamme, P., Daneshvar, M. I., Dewhirst, F. E., Paster, B. J., Kersters, K., Goossens, H. \& Moss, C. W. (1995). Chemotaxonomic analyses of Bacteroides gracilis and Bacteroides ureolyticus and reclassification of B. gracilis as Campylobacter gracilis comb. nov. Int J Syst Bacteriol 45, 145-152. 